\title{
RIVER AS CENTER AND/OR BARRIER. THE PERIPHERAL URBAN LANDSCAPES OF ROMANIAN DANUBE CITIES
}

\author{
Stan Angelica Ionela \\ Assoc. Prof. PhD Architect Urbanist \\ Urban and Landscape Planning Department, Faculty of Urbanism, "Ion \\ Mincu" University of Architecture and Urbanism, Bucharest, (ROMANIA) \\ Angelicastan[at]yahoo.com
}

\begin{abstract}
For the cities on its shores, Danube represents a matrix of development, the origin of growth and the birth of a specific landscape, shaped up to the horizon of the transformations they have suffered during centuries. The landscapes of these cities gradually emerged and overlapped with the Danube natural landscape, taking over its conditions and constraints. Everything that could have influenced the man-made landscape, also have been distilled and adapted: the land declivity, the water's strength, the wetlands, the forests, the wilderness areas, the islands, the fishing boats, the people themselves.

In the context of looking for a Danube brand, as the paper is part of the INTERREG-DANUrB project ${ }^{1}$, beyond its existing borders, limits, barriers, the Danube urban landscape - seen both from the inside (from the city), and from the outside (from the water) is more than an impressing image, but speakes about how the river have given birth and created the people life opportunities, and also how it have imposed strong barriers and limits for urban development.

For the Romanian Danube cities, the peripheral landscapes have assimilated both the natural character, the ante-industrial identity, and the remains of the (post-) industrial age, now showing a combining pattern of different and contradictory elements.
\end{abstract}

Keywords: Water Edge Planning, Waterfront landscape, Industrial area, City barrier words

\section{INTRODUCTION}

After 1950, a series of Romanian Danube towns have developed mainly based on the artificially implanted industries, which often diverted the traditional character of the city, and introduced new visual elements, in a vanity or even aggressive contrast with the pre-existing landscape. These industrial-time markings have generated and maintained a specific, unmistakable peripheral landscape. The brand of some cities, their image in the eyes of the inhabitants themselves, and in the eyes of their visitors, had become, until 1990-2000, strictly related to the industrial landscape, whether it was even the industrial harbor area or other more or less-related industries of river activity.

Cities as Braila, Galati, Giurgiu, Tulcea or Calarasi, as representative middle-sized Romanian cities on Danube (between 50000 and 250000 inhabitants), experienced

\footnotetext{
${ }^{1}$ http://www.interreg-danube.eu/approved-projects/danurb
} 


\section{\#3/2018 URBAN CHALLENGES}

this landscape transformation specifically on the territories situated on the river banks, where the harbors, and related industries have developed.

The urban landscape of post-industrial cities situated on Danube can be reappreciated, and re-valued, assimilating both its ante-industrial identity, and its remains of the (post-) industrial age [1]. As areas with the strongest dynamics, the outskirts of a city are associated with an urban landscape which is often in contrast or even in contradiction to the natural landscape. We could say that the landscape of the peripheries is by far the place of this defiance [2] of the struggle between the Nature and the City. At the same time, the landscape of the peripheries is just a stage in the development of an urban landscape, one able to integrate with, and adapt to the Nature. Therefore, it's not just the scene of a struggle but, at the age of its maturity (sustainability), the scenery of a symbiosis.

\section{METHODOLOGY}

The paper compares the essential structures of the urban landscape seen both from this two points of view (land and water), within the fifth of Romanian Danubian towns, choosen by their specific patterns of the relation between the urban morphology and the Danube landscapes, as adaptive response to the natural conditions. Comparison criteria become tools for assessing their urban landscape quality, and also to generate and suggest axes for intervention in order to improve and valorise landscape heritage, as part of the local urban identity and culture. The essential structures of the urban landscape is revealed by a double perspective: from the inside urban fabric and from the water. The method is helpful in showing the way in which the urban structure - both by its original centrality, and by its recent peripheral development - is answering to the opportunity of opening and focalizing toward Danube. In all studied cases, these peripheral landscapes have two main combined characters - the natural one, coming from Danube natural capital, which have act as a barrier for the city development, and the industrial one (mainly harbor activities), which have created an artificial image, in contrast with the image of the city.

\subsection{DANUBE URBAN LANDSCAPE ASSESMENT CRITERIA}

The analysis of Danube's urban landscape in these five cities therefore calls for an adapted, graded grid, able to capture this link between the city, center and periphery, and water, the ambivalence and the balance / imbalance patterns between natural and built elements. Especially the ex-industrial areas, whose port activities have fallen lately, industries that have collapsed across the country, unable to keep up the pace of technology, have imposed in the landscape of these cities contrarial segments that contravene the natural and the traditional city values.

This criteria gril is composed by several items, as follows:

$A$. The Landscape general character / on a scale from 5 (very good/ operational) to 0 (very bad, ruined)

1. The state of buildings and equipment- if operational, abandoned, ruined, or empty spaces

2.The physical condition of buildings, cliffs, public spaces

3. The status of environmental factors (risks, aggressions, protected areas)

B. The Landscape Image / from outside (water) / on a scale from (2)- positive,

(1)- neutral, (0) - negative

1. Scenic qualities of the river bank (rhythmicity, accents, landmarks) 


\section{\#3/2018 URBAN CHALLENGES}

2. Urban / natural front overlays

3. Public attractiveness (color, lighting, places where usually are taking place events, etc.)

C. The Landscape Image from inside (land) / on a scale from (2)- positive, (1)neutral, (0) - negative

1. Scenic qualities of the urban fabric towards water (openings, scatter points, landmarks)

2. Main urban fabric structure orientation

3. Green infrastructure in relationship to natural landscape condition

D. The Landscape Value / on a scale from 5 (very high) to 0 (no value)

1. Rarity / uniqueness

2. Architectural representativeness

3. Ambient qualities (quietness, evocative)

4.Environmental qualities (ecosystems contiguity and diversity )

\section{DANUBE AS CENTER}

All five selected cities have evolved from ancient Dacian or Getic settlements situated on the Danube, where the river's whims would have been managed and turned into advantages by their inhabitants, becoming flourishing ports. The tumultuous history of countless wars during the Ottoman Empire imposed that these urban nuclei, inhabited since the 5th century B.C., have become citadels, meaning settlements with a military function of defense. Their landscape, molded on the flat land of the Danube, was, in times of peace, dominated by fishing boats and merchants which were selling their goods on the river banks. In Braila, the Danube cliff is still keeping the mark of the places where these goods were deposited: the docks. The wars have brought the defense towers into the urban landscapes of these cities and, requested by the need of enemys' observation on the Danube [3]. The centrality of these cities is clearly oriented towards the Danube. This orientation is either direct, axial (Tulcea), or semi-circular (Braila, Giurgiu) or linear (Calarasi, or cell (Galati). Until the time of the communist era, this orientation was a natural, organic one from the successive stages of growing urban tissues. Interventions of the 1950-1980 systematization of city centers have in many cases led to the mutilation of this intimate relationship between the city centers and the Danube. In cities like Tulcea and Galati, portions of historical tissue have been demolished and replaced by large and dry "civic squares" meant to host the fortified gatherings of the people in adoration of the dictator Ceausescu. Paradoxically, although this gesture has severely affected the city's patrimony and built landscape, socially, the link between citizens and the Danube has intensified. Missing the identity places within the traditional center of the city, the inhabitants have (re)found the banks of the Danube as the spaces of the promenade. 
Galați

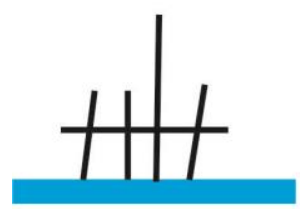

cell

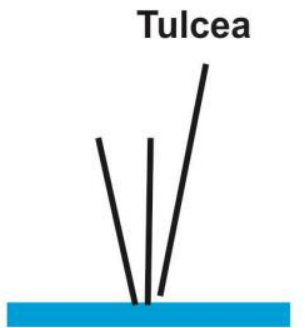

angular
Giurgiu - Ruse

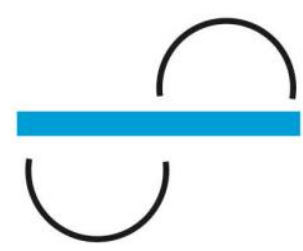

duble semicircular
Brăila

semicircular

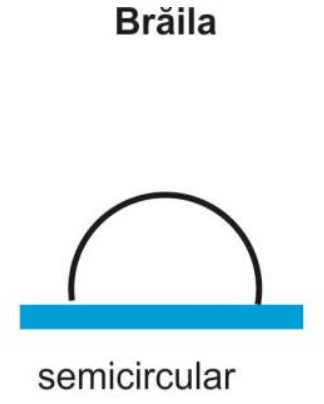

Călărași

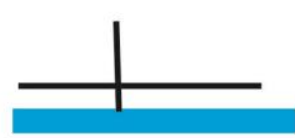

linear

Figure 1. The main orientation of the urban fabric in the five cities analyzed, showing the relation type with the Danube. Source: author

\section{DANUBE AS BARRIER}

But what makes a particularity of the Romanian Danube cities, and probably of many other towns located on a shore of a water, is the ex-centric position of the city center towards the entire urban fabric. This position follows the connection point of the ancient settlement with the Danube, and the urban tissue is developed according to the main territorial opportunities, conditioned by the natural barriers.
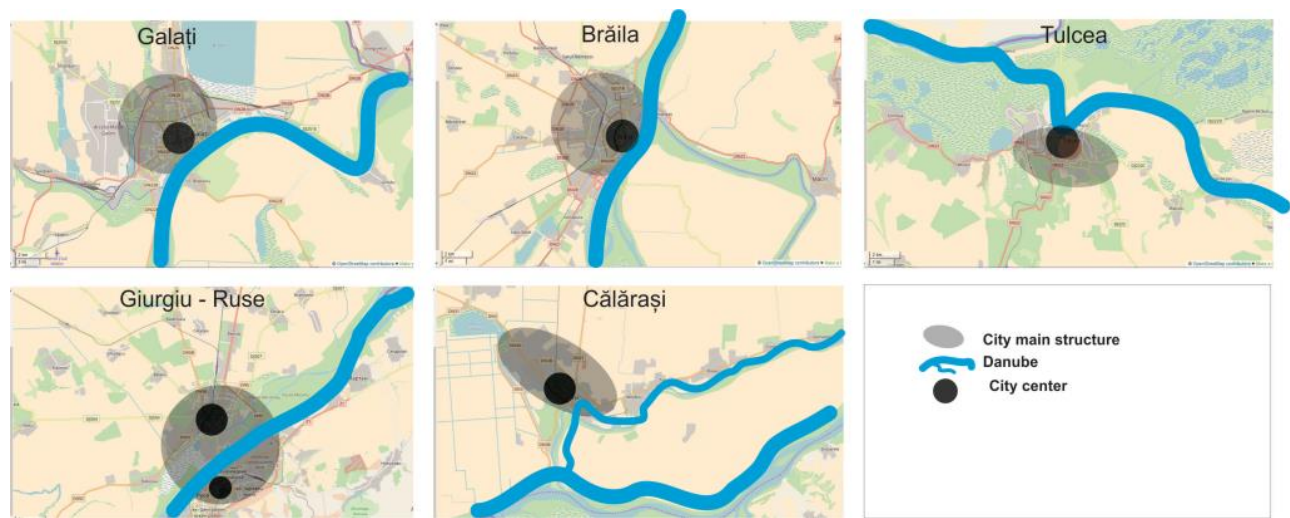

Figure 2. The position and relationship between the main urban structure, the center and Danube, in each of the study cases, showing the ex-centricity and the peripheral conditon of the Danube cities.

Source: author 
The landscape of this umbilical connection of the city with the Danube can be analyzed in the historic images that reveal these germinations from the initial point of the urban tissue. During the communist regime, the urban landscape, especially the landscape seen by the water (as in the case of Tulcea) have been dramatically changed under the "systematization" communist directives which have intervened very brutally on the cities' silhouettes and created a concret barrier between the Danube and the city.

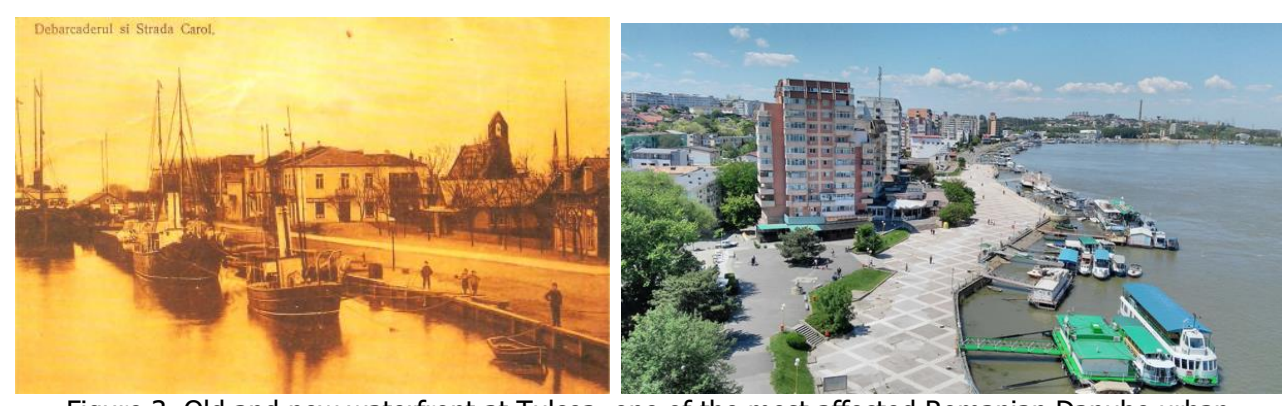

Figure 3. Old and new waterfront at Tulcea, one of the most affected Romanian Danube urban landscape, transformed during the communist period into a concrete wall, face to the water. Source of pictures: http://www.e-antropolog.ro, http://www.obiectivtulcea.ro

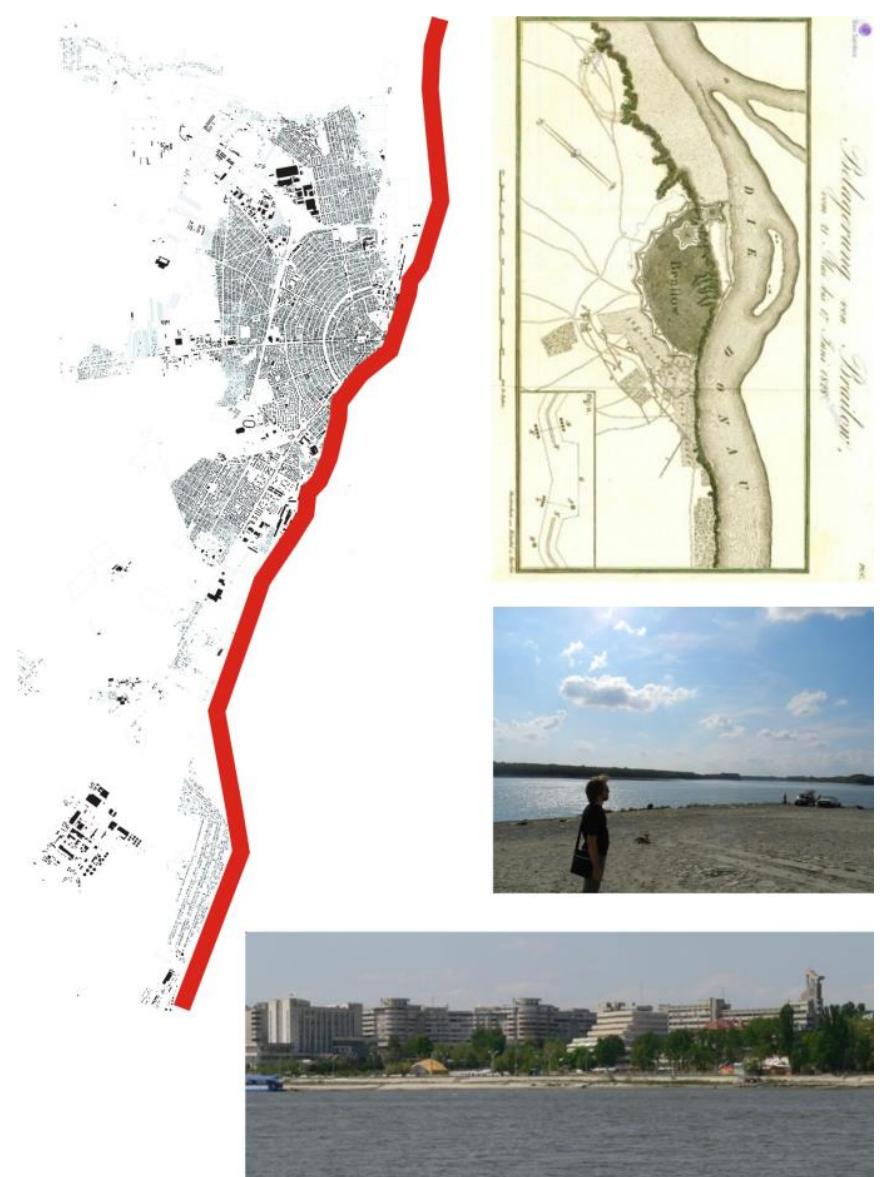

Figure 4. Water limits at Braila - the historic imprint of the city evolution, and the waterfront as landscape/image seen from the river, showing a spatial contrast between built/ center and empty / periphery. Source: author 


\section{\#3/2018 URBAN CHALLENGES}

The case of Braila shows a city broken into multiple fragments, by strong different limits, ones which separate and break the urban fabric into incommunicable islands, and limits that join and mix up things and make them endurable. The most important limit of Braila is the waterfront to Danube- a limit which historically connects and opens the city in terms of economy and culture. As physical space, the contact line of the city with the Danube's water is partially a strong built tissue (inside the historical center), and partially (in north and south part), a fluid and empty limit, specfic to a peripheral landscape.

\subsection{A dual, hibrid landscape}

In all analized cities, the peripheral areas of the riverfront are varying according to the activities that they host. Because of the lack of vison and investment in the peripheral areas, the decline of industrial activities have not been replaced with other (urban) activities, but with sporadic and uncontrolled uses of this spaces. So, this situation imposes a presence of a dual peripheral landscape: a) the industrial one, metallic, aggressive, rusted, and almost abandoned landscape, having a disorganised appearance, in a desolating and destructive decline or marked by inconsistency (Braila, Giurgiu, Calarasi), and b) natural/ vague spaces, sporadically used as promenade, or as fishing places, or/ and for other relaxing activities during summertime, impressive landscapes due to their wilderness (sometimes only a few steps away from the city centre- case of Braila), with peaceful images of the an eternal Danube, with floodable banks during spring [4].

Also, the urban landscape of these cities, as a structural condition, is a hybrid as result of a continuous negotiation between the Danube's force (floods) and man's strength (in history - wars, social evolution, presently - urban development, decline, migration, etc.).
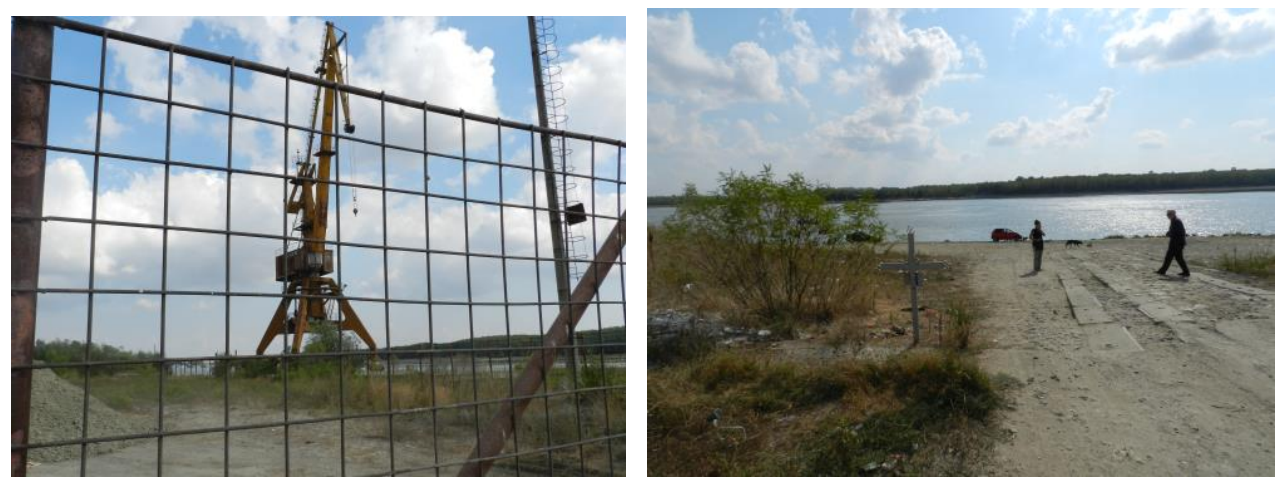

Figure 5. The dual landscape of the peripheries of the Danube cities, showing a contrast and a conflict. One type is related to the ex- industrial sites, now in strong decline, and the other one is an empty, almost natural, sporadically used territory near the water. Case of Braila. Source: author 


\section{\#3/2018 URBAN CHALLENGES}

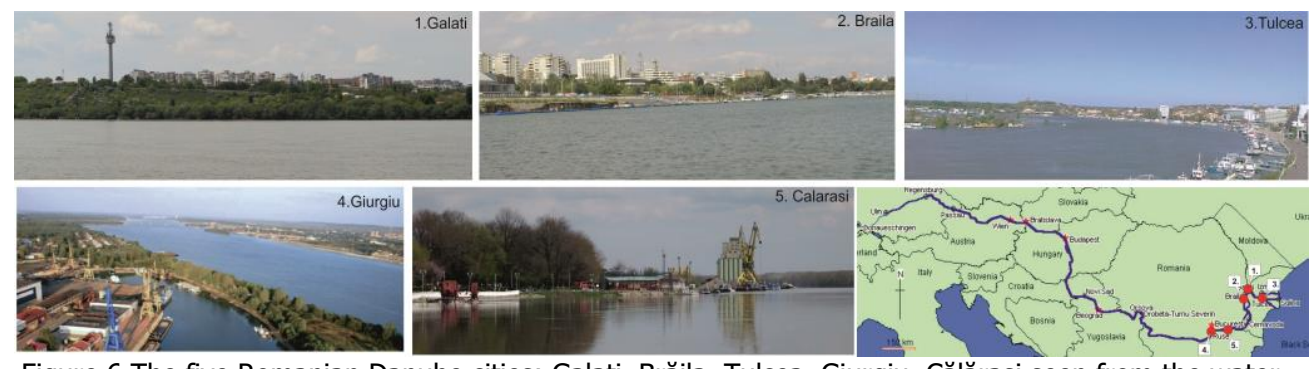

Figure 6 The five Romanian Danube cities: Galați. Brăila, Tulcea, Giurgiu, Călărași seen from the water. The hybrid landscapes combining natural elements, inside urban identities/ landmarks and industrial plants at peripheries.

\section{RESULTS}

The study recommends the application of the entire previously mentioned criterion grid, as this tool allows a tangible appreciation of the landscape character and values of these cities, taking into account all the necessary elements, accordingly grouped: the physical condition of buildings, cliffs, public spaces, the status of environmental factors, protected areas, the scenic qualities of the river bank (rhythmicity, accents, landmarks), the Urban / natural front overlays, the public attractiveness (color, lighting, the urban fabric towards water (openings, scatter points, landmarks), the main urban fabric structure orientation, the green infrastructure in relation to the natural landscape condition, rarity / uniqueness, architectural representativeness, ambient qualities (quietness, evocative) contiguity and diversity.

In a testing stage of this model tool, we applied the criterion grid within DANUrB project, and thus, have discovered the following scores for the five case - studies took into consideration. The very close score obtained by each of them is reflecting a balance in apreciation and also evident similarities of the cities themselves.

\begin{tabular}{|c|c|c|c|c|c|}
\hline \multirow[t]{2}{*}{ Score } & $0-5$ & $0-5$ & $0-5$ & $0-5$ & \multirow{2}{*}{$\begin{array}{l}\text { General } \\
\text { score }\end{array}$} \\
\hline & $\begin{array}{l}\text { The } \\
\text { Landscape } \\
\text { general } \\
\text { character }\end{array}$ & $\begin{array}{l}\text { The } \\
\text { Landscape } \\
\text { Image / } \\
\text { from outside } \\
\text { (water) }\end{array}$ & $\begin{array}{l}\text { The } \\
\text { Landscape } \\
\text { Image from } \\
\text { inside (land) }\end{array}$ & $\begin{array}{l}\text { The urban } \\
\text { Landscape } \\
\text { Value }\end{array}$ & \\
\hline Galati & 3 & 2 & 4 & 4 & 13 \\
\hline Braila & 3 & 3 & 2 & 4 & 12 \\
\hline Tulcea & 2 & 1 & 3 & 4 & 10 \\
\hline Calarasi & 1 & 3 & 4 & 4 & 12 \\
\hline Giurgiu & 4 & 2 & 3 & 1 & 10 \\
\hline
\end{tabular}

\section{CONCLUSIONS}

The Danube was an umbilical element, a center of these cities development, not only spatial but also cultural, social, economic. At the same time, the Danube is a limit and gave rise to other limits related to the use of its adjacent territories, industries, recreational areas, natural areas. With many of these limits, cities historically co-exist and co-produce themselves. In many cases, there are positive 


\section{\#3/2018 URBAN CHALLENGES}

limits - those which enhance relationships and collaboration with the parts nearby. But there are also negative limits, barriers, leading to urban decline, to fracture, to ruin and insulation. Unfortunately, many of this last limits are considered (by people, by local authorities) as fatalities, given by the belief that "nothing can be done", or that "everything's useless". And Danube can teach us that the worst barriers are in the people minds, making them afraid to cross its waters.

Addressing the Danube cities through their peripheral landscape awares on the fact that urban development can lead to barriers and disparities, and doesn't always have a positive impact on local identity [5]. The periods of transition between different stages of development are strongly reflected in the peripheral territories of these cities, receiving the full shock of these dynamics. In addition, the tangency with the Danube increases both the vulnerabilities, and the potential for transformation.

\section{REFERENCES}

[1] Buda, O, (2008). O antropologie a marginalului, Editura Caligraf, București [2] Stan, A, (2013). „Morphological Patterns in Bucharest Periphery", Pascariu, G, Alexandru, M, Faurest, K, (eds.) "Integrated Planning and Design for Sustainable Urban Peripheries in Europe: River Dâmbovița in the South East from Văcărești to Popești-Leordeni", Ed. Univ.Ion Mincu, Bucuresti, 24-25.

[3] Munteanu, A. (1975). Tulcea, Bucuresti, Editura Sport-Turism

[4] Munteanu,I (2014), Brăila acum o sută de ani: 1915, Ed.Proilavia of the Panait Istrati County Library, Brăila

[5] Giffinger, R; Suitner, J. (2010). „Danube region strategy: Arguments for a territorial capital based multilevel approach". Spatium.

Article distributed under a Creative Commons Attribution-

NonCommercial-NoDerivatives 4.0 International License (CC BY-NC-ND).

Received: March 30, 2018

Accepted: April 27, 2018. 